\title{
Assessment of Stocking Activities on the Native Brown Trout Populations from Nestos River (Southern Balkans) Inferred by mtDNA RFLP and Sequencing Analyses
}

\author{
Ioannis A. Giantsis ${ }^{1,2}\left(\mathbb{D}\right.$, Argyrios Sapounidis ${ }^{3}$ D, Emmanouil Koutrakis ${ }^{3}$ and Apostolos P. Apostolidis ${ }^{1, *}$ \\ 1 Lab of Ichthyology \& Fisheries, Department of Animal Production, Faculty of Agriculture, Forestry and \\ Natural Environment, Aristotle University of Thessaloniki, 54124 Thessaloniki, Greece; igiants@agro.auth.gr \\ 2 Department of Animal Science, Faculty of Agricultural Sciences, University of Western Macedonia, \\ 53100 Florina, Greece \\ 3 Fisheries Research Institute-ELGO “DIMITRA”, Nea Peramos, 64007 Kavala, Greece; \\ asapoun@inale.gr (A.S.); manosk@inale.gr (E.K.) \\ * Correspondence: apaposto@agro.auth.gr
}

check for updates

Citation: Giantsis, I.A.; Sapounidis, A.; Koutrakis, E.; Apostolidis, A.P. Assessment of Stocking Activities on the Native Brown Trout Populations from Nestos River (Southern Balkans) Inferred by mtDNA RFLP and Sequencing Analyses. Appl. Sci. 2021, 11,9034. https://doi.org/10.3390/ app11199034

Academic Editor: Andrea Ballini

Received: 25 August 2021

Accepted: 26 September 2021

Published: 28 September 2021

Publisher's Note: MDPI stays neutral with regard to jurisdictional claims in published maps and institutional affiliations.

Copyright: (c) 2021 by the authors. Licensee MDPI, Basel, Switzerland. This article is an open access article distributed under the terms and conditions of the Creative Commons Attribution (CC BY) license (https:/ / creativecommons.org/licenses/by/ $4.0 /)$.

\begin{abstract}
Alien fish introductions, conducted towards the ichthyofauna enhancement in local drainages, have been occasionally proved harmful for the indigenous freshwater fish populations. The present study was designed to assess the impact of stocking activities, carried out in the past decades with fingerlings originating from Acheloos river hatcheries, on the native trout (Salmo sp.) populations of Nestos River, Greece. Trout specimens collected from several tributaries of Nestos River and were analyzed by means of PCR-RFLP and sequencing targeting the mitochondrial ND5-ND6 genes and the entire control region, respectively. It should be mentioned that trouts from Acheloos mainly belong to the marmoratus mitochondrial DNA (mtDNA) lineage, while the autochthonous trouts from Nestos belong to the Adriatic lineage. Both methodologies demonstrated that most samples from the three tributaries located at the lower part of Nestos constitute offspring of the fingerlings transferred from Acheloos hatcheries. Therefore, these tributaries have been strongly affected by stocking activities with a potential complete loss of their autochthonous trout. On the other hand, it seems that trout populations from higher altitude tributaries have not been affected by stockings. Hence, efforts should be undertaken in order to prevent the prevalence of the nonindigenous translocated Salmo in higher altitude tributaries, in conjunction with a management plan designed for the total trout populations from the area, speaking of which it has been recently included to the National Park of Rodopi Mountains.
\end{abstract}

Keywords: Salmo spp.; brown trout; translocations; conservation; genetic profile; Nestos River; tributaries; stocking

\section{Introduction}

Intentional introductions of alien fish species, or translocations of fish populations belonging in the same species, genus or family, to different ecosystems, have been taken place in Greek inland waters for nearly one hundred years, aiming to the enhancement of the ichthyofauna of several local drainages [1]. In many cases, however, these actions have been proved not only unnecessary, but also harmful for the indigenous freshwater fish populations [2]. Such incidents, unfortunately, include the numerous, still debatable, Salmo taxa described in Greece, which exhibit considerably high levels of phenotypic and genetic variation [3]. As a result of these stocking activities, the non-indigenous populations or species have hybridized with the local ones putting in danger their unique genetic profile [4].

The Nestos (Mesta) River in north-eastern Greece represents such a case, where the local populations of trout, inhabiting the tributaries of the river, have been affected by 
stocking activities conducted many times in the past. Specifically, in the mid-1970s, 20,000 Salmo trutta fingerlings of domestic strains, originating from a fish farm in Acheloos River (central Greece), were released in the lower parts of Nestos' tributaries, Arkoudorema and Diavolorema [1,5]. Subsequent translocations, some of which remaining unrecorded, have also been conducted during the next decades in other streams of Nestos, in Greece or Bulgaria, with trout from the same river or other southern Balkan's drainages. For instance, in 2011 in Arkoudorema River, the local Hunting Club with the assistance of the Forestry Agency released several thousands of trout fingerlings (Department of Fisheries, Regional Unit of Drama, Administrative Region of Eastern Macedonia and Thrace, Greece-personal communication), while unconfirmed information from fishermen, report also brown trout translocations from former Czechoslovakia to Bulgaria, in the second half of the 20th century without any additional information [6]. It must be noted that Nestos River together with its tributaries in the area, in the last decade, have been included in the protected area of the National Park of Rodopi Mountains, Administrative Region of Eastern Macedonia and Thrace, Greece.

We stress that the taxonomic status of the brown trout from Nestos River remains a matter of debate [7]. Economidis et al. [8], based on morphological characters, reported the trout from Nestos River as Salmo macedonicus. On the other hand, according to the morphological analyses of Kottelat and Freyhof [9] and Simonovic et al. [10], Salmo macedonicus is a distinct lineage distributed in the northern part of Axios River, North Macedonia. However, this taxonomic status is not supported by mtDNA data [11]. It is notable that Lo Brutto et al. [11] did not confirm the presence of two species as suggested by several authors but support the existence of two different allopatric morphotypes (S. trutta macedonicus and S. trutta pelagonicus), which evolved separately. Similarly, although a previous mtDNA sequence analysis clustered some native Nestos haplotypes in a distinct clade, the classification of brown trout from Nestos River as a valid species was not supported [5]. On the other hand, the taxonomic status of the trout from Acheloos River is also debatable as according to Kottelat and Freyhof [9] it is classified within the S. farioides complex, whereas molecular genetic analyses did not support its taxonomic distinctiveness [4].

In a previous study conducted approximately 25 years ago on trout samples from the Nestos River, Apostolidis et al. [12] applying the mitochondrial DNA (mtDNA) PCR-RFLP methodology, found that 17 out of the 22 individuals examined had the same genotype with the prevalent genotype of the samples originating from Acheloos. Similarly, in a posterior mtDNA sequence analysis of these samples, Apostolidis et al. [5], found that five out of the nine examined individuals from Nestos, had the same haplotype with the fish collected from Acheloos. The presence of these haplotypes in the Nestos population most probably reflected the stocking from the fish farm originating from the Acheloos River and these fish were probably offspring or hybrids of the translocated brown trout.

The main objective of the current work was to evaluate the impact of the previous stocking activities on the native trout populations of the Greek part of Nestos River and to compare the current results with those derived from the previous genetic studies $[5,12]$, using identical mtDNA markers albeit in a more expanded sampling scheme.

\section{Materials and Methods}

Trout samples included in this study were collected from several tributaries of Nestos River, during different periods of 2007-2014 (Table 1, Figure 1). All sampling sites are within the limits of the protected area of the Rodopi Mountain Range National Park, according to the Joint Ministerial Decision of the Greek State 40379/01-10-2009. Fish were caught by electrofishing and a small piece of the fin tissue was obtained from each specimen for the DNA extraction, such that after the release of the fish back into the water, their swimming ability was not affected, and their survival was secured. DNA extraction was performed using the protocol of Hillis et al. [13] and samples were genotyped using a combination of PCR-RFLP and sequencing analysis in different mitochondrial DNA segments. 
Table 1. Sample collection information.

\begin{tabular}{cccc}
\hline Code & $\begin{array}{c}\text { Sampling Location in the } \\
\text { Greek Territory }\end{array}$ & Number of Samples & Sampling Time \\
\hline MOU & Mousda stream & 9 & July 2008 \\
VATH1.1 & Vathyrema (Kalikarpo) & 5 & May 2007 \\
VATH1.2 & Vathyrema (Kalikarpo) & 3 & September 2008 \\
VATH1.3 & Vathyrema (Kalikarpo) & 5 & June 2012 \\
VATH1.4 & Vathyrema (Kalikarpo) & 3 & March 2014 \\
VATH2 & Vathyrema (Elatia forest) & 7 & July 2013 \\
DIAV & Diavolorema & 6 & June 2012 \\
ARK1 & Arkoudorema-Drama1 & 11 & June 2012 \\
ARK2 & Arkoudorema-Drama2 & 6 & June 2014 \\
FAR & Total Farasino & 11 & June 2012 \\
& & 66 & \\
\hline
\end{tabular}

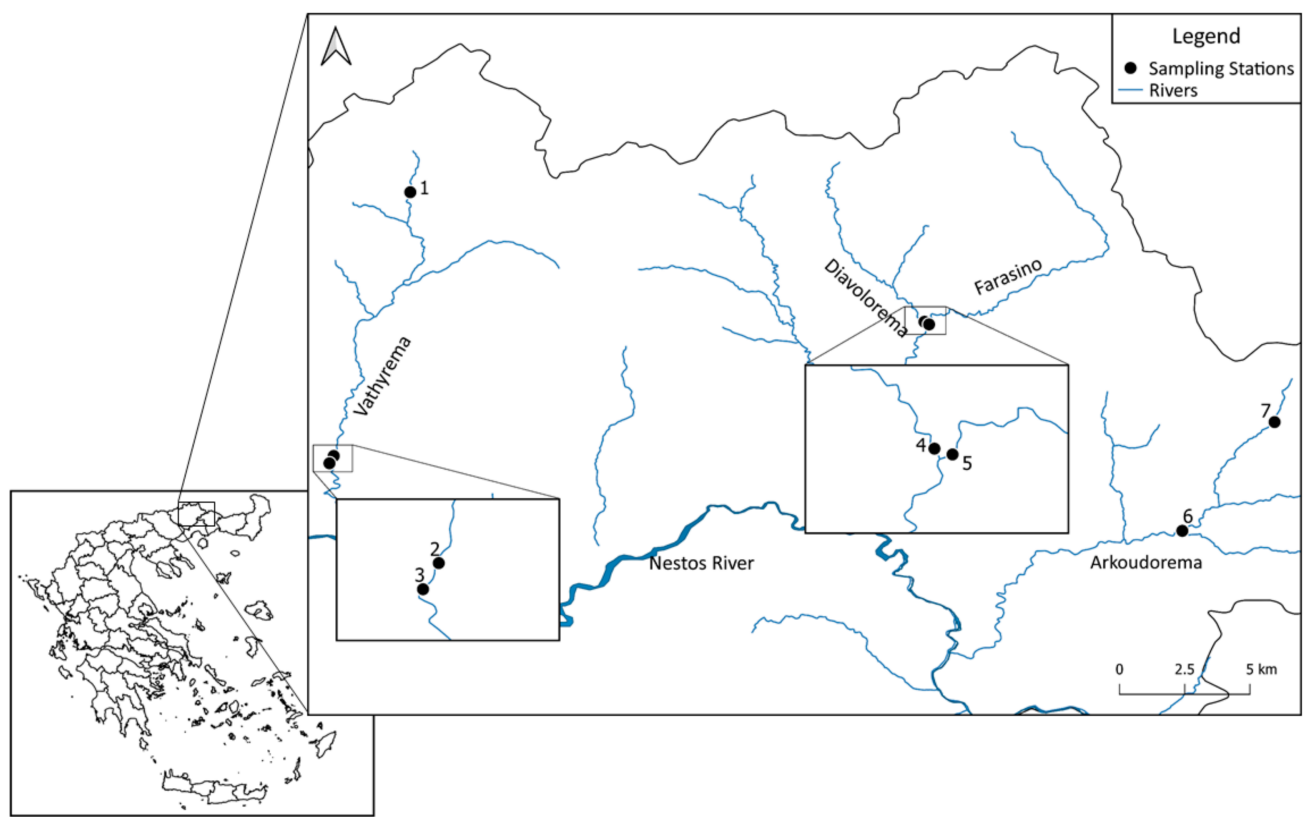

Figure 1. Nestos tributaries (southern Balkans) where the trout samples were collected. Sampling stations are indicated as a black dot [1. Vathyrema (Elatia forest), 2. Vathyrema (Kalikarpo), 3. Mousda stream, 4. Diavolorema, 5. Farasino, 6. Arkoudorema-Drama1, 7. Arkoudorema-Drama2].

Restriction Fragment Length Polymorphisms (RFLPs) were examined on a mtDNA segment, embedding NADH dehydrogenase subunits 5 and 6 genes (ND5 and ND6 genes). The primers (ND5/6-A, ND5/6-B) and the PCR conditions were applied as described by Nielsen et al. [14]. Amplified segments (ND5/6), approximately $2500 \mathrm{bp}$ in length, were digested with the restriction endonucleases $A l u \mathrm{I}$ and $H a e \mathrm{III}$ and restriction profiles were observed in $2.5 \%$ agarose gels. Digestion of the ND5/ 6 region with those two enzymes in the Nestos trout samples, produces two different genotypes that distinguish the indigenous from the non-indigenous translocated fish [12].

For the sequence analysis, the entire control region $(\mathrm{CR})$ was amplified with the primer pair HN20-LN20 [15] in 18 individuals comprising at least 2 individuals from each sampling site. PCR products were purified using the NucleoSpin PCR Clean-up Kit (Macherey-Nagel, Düren, Germany) and sequencing was performed bidirectionally with both HN20 and LN20 in an ABI Prism 3730XL automatic capillary sequencer and applying the BigDye Terminator v3.1 kit (Applied Biosystems ${ }^{\circledR}$, Foster City, CA, USA). Sequences were edited and aligned with the software MEGA version 5.05 [16]. Finally, in order to visualize the relationships among different haplotypes a maximum likelihood dendrogram was constructed using MEGA v. 5.05. 


\section{Results and Discussion}

The restriction profiles after the digestion with $A l u \mathrm{I}$ and HaeIII enzymes are shown in Table 2. Identical profiles using the same enzymes were observed by Apostolidis et al. [12]. All individuals originating from Mousda stream (Falakro Mountain, Greece), as well as the majority of those from Arkoudorema-Drama1 and from Vathyrema near Kalikarpo, had the same genotype with the prevalent one from Acheloos populations (composite genotype BB), whereas in all trout samples from Diavolorema, Farasino, and Vathyrema near Elatia forest, the autochthonous haplotype (composite genotype AA) was observed (Table 3). No composite genotype $\mathrm{AB}$ or $\mathrm{BA}$ was observed.

Table 2. Restriction profiles (in base pairs) after the digestion with AluI and HaeIII. Fragments with sizes smaller than $100 \mathrm{bp}$ are not shown.

\begin{tabular}{cccc}
\hline & AluI & & \multicolumn{2}{c}{ HaeIII } \\
\hline A & B & A & B \\
& 1090 & 870 & 710 \\
940 & & 710 & 580 \\
490 & 490 & & 570 \\
280 & 280 & 570 & 290 \\
250 & 250 & 170 & 170 \\
230 & 230 & 130 & 130 \\
150 & & & \\
\hline
\end{tabular}

Table 3. Haplotypes (composite genotypes) and haplotype frequencies of the examined samples as revealed by RFLPs.

\begin{tabular}{|c|c|c|c|c|c|c|c|c|c|c|}
\hline \multirow{2}{*}{$\begin{array}{l}\text { Composite } \\
\text { Genotype }\end{array}$} & \multicolumn{10}{|c|}{ Sample } \\
\hline & MOU & VATH1.1 & VATH1.2 & VATH1.3 & VATH1.4 & VATH2 & ARK1 & ARK2 & DIAV & FAR \\
\hline AA & & & & $1 / 5$ & $1 / 3$ & $7 / 7$ & $3 / 11$ & $6 / 6$ & $6 / 6$ & $11 / 11$ \\
\hline $\mathrm{BB}$ & $9 / 9$ & $5 / 5$ & $3 / 3$ & $4 / 5$ & $2 / 3$ & & $8 / 11$ & & & \\
\hline
\end{tabular}

In the sequence analyses, the entire mitochondrial control region (1021 bp) was successfully aligned for 18 individuals and revealed 10 variable sites that defined four different haplotypes, all of which were recorded for the first time. The three out of four haplotypes (haplotypes A, B, C) were observed among the 38 individuals that had the AA composite genotype in RFLPs analyses (supposed autochthonous individuals). In haplotypes A and $B$ the first 305 nucleotides in the side of tRNA proline were identical with haplotype $E$ (GenBank accession number: U63790) described in Apostolidis et al. [5], which was found in Nestos trouts that were not affected by the stockings, while haplotype $\mathrm{C}$ was one mutational step distant from haplotype E. Similarly, the 305 nucleotides in the side of tRNA proline in haplotype $D$ were identical with the haplotype " $G$ " (GenBank accession number: U63792) in Apostolidis et al. [4] that was observed in trouts from Acheloos River. This haplotype was observed in a specimen from Vathyrema that had the BB genotype in RFLPs. Thus, sequencing results were in accordance with RFLP results.

Brown trout populations of the southern Balkans are characterized by extensive genetic diversity [3,12]. It is worth noting that out of the five distinct mtDNA phylogenetic lineages that have been revealed throughout Salmo trutta range, four have been detected in the Balkan area [5]. The maximum likelihood dendrogram of Figure 2, depicting the phylogenetic relationships among the four haplotypes found in this study, revealed that haplotypes A, B, and C were clustered together and supported with high bootstrap values with haplotype ADcs1 (AY836330, [17]), which is presumed to be the ancestral haplotype in the Adriatic (Ad) major phylogenetic lineage [3], and thus belong to the $\mathrm{Ad}$ lineage. On the other hand, haplotype $\mathrm{D}$ was clustered in the same branch with haplotype MAcs1 (AY836365, [17]), hence belongs to the marmoratus lineage. These inferences are in accordance with previous mtDNA studies [5] that revealed that the trouts from Acheloos 
River mainly belong to the marmoratus major phylogenetic mtDNA lineage, while the autochthonous trouts from Nestos River belong to the Adriatic lineage.

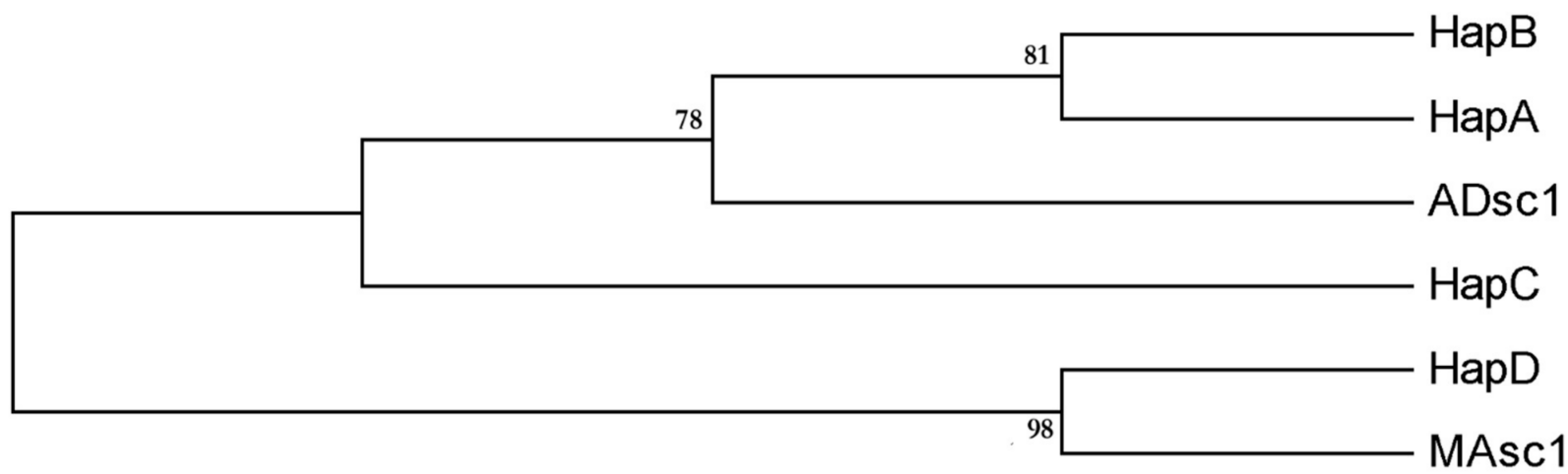

Figure 2. Maximum-likelihood consensus dendrogram depicting the genetic relationships among the four haplotypes observed in the current study, along with one marmoratus and one Adriatic sequence, obtained from GenBank. Bootstrap values greater than $60 \%$ are shown on the branches.

Although haplotypes A, B, and C have not been described so far, they only differ by two to three nucleotide substitutions from the most consensus Salmo trutta sequences obtained from the GenBank database (AY836330, AY836348, AY836349, [16]), reflecting pairwise sequence divergence lower than 0.01 . Therefore, mtDNA markers do not support the classification of trout from the Greek part of Nestos River as a valid distinct species. However, since mtDNA represents only a small part of the eukaryotic genome, and particularly concerning Salmo species where there are several cases of conflict between mitochondrial and nuclear DNA phylogenies, e.g., [4,12,18], further genetic analyses including Salmo spp. populations from a wider geographical range, i.e., such as Balkan peninsula, using neutral nuclear markers such microsatellites or SNPs are required in order to clarify the taxonomic distinctiveness of Nestos trout. On the other hand, from an evolutionary point of view, it is genetic integrity rather than purely taxonomic status that is of interest. Further, it should be also pointed that for conservation purposes, it is worth considering a morphotype, such is the Nestos River trout, as a distinct species, with purpose not to be neglected [18].

In general, translocations of fish species towards the erroneous enhancement of local habitats, although often are characterized as of good intention, are considered among the deterministic threats causing extinction [19]. Apart from the obvious risk of pathogen introduction and infection of closely related species [20], the impact on ecosystem stability could be catastrophic. Introduced species may not only be antagonistic to the inhabitants of the new environment, but also may hybridize with local genetically closely related populations. For instance, at least four alien freshwater fish species, i.e., Gambusia holbrooki, Carassius gibelio, Pseudorasbora parva, and Lepomis gibbosus have currently widespread their distribution in Greek rivers and streams [21].

On account of anthropogenic intra or inter-specific hybridization within Salmo trout populations, the real conservation status is often obscured [22]. Our results provide evidence that the trout introductions threatened the local trout populations with irreversible impacts at some streams. RFLP and sequencing analysis agreed that all the trout samples from Mousda stream and most of those from Arkoudorema-Drama1 and from Vathyrema near Kalikarpo (Figure 1), which had the prevalent Acheloos genotype, constitute, namely, offspring of the fingerlings transferred in the 1970s and thereafter, the latest being in 2011 in Arkoudorema River, whereas no genotype that would indicate translocation of trouts from a different area was found. Hence, these tributaries have been severely affected by the stocking activities with a potential complete loss of the autochthonous trout particularly in the Mousda stream. On the contrary, local brown trout populations from higher altitude tributaries, i.e., Diavolorema, Farasino, Vathyrema near Elatia forest and ArkoudoremaDrama 2, probably have not been affected by the stocking activities, since there was no 
specimen in which the Acheloos genotype was observed. Obviously, physical barriers, such as waterfalls, located between the lower and the higher parts of Vathyrema and Arkoudorema, did not allow the upstream movement of non-indigenous translocated trout, or their offspring, protecting in this way the unique genetic profile of the brown trout in these tributaries. Therefore, efforts should be undertaken in order to prevent the prevalence of the non-indigenous translocated Salmo species in the aforementioned tributaries. In that context forbiddance of the upstream movements of these Salmo species or even elimination of the non-indigenous translocated trout from the lower part of the tributaries are of high importance.

Finally, in order to conserve the local trout population, special attention should be paid to prevent any Salmo population transfer towards these tributaries, and especially the not affected ones in the future, by prohibiting any further stocking actions. Since the whole area belongs to the National Park of Rodopi Mountains and in an effort to have a complete conservation of the species, a management plan of the local trout of the area is necessary that could include a complete study of the fish populations of the river basin and of the genetic structure of the local population. Unfortunately, the Management Body of the National Park does not have the authority to approve or not any stocking action. According to the legislative framework of the Greek State (Royal Degree 142/1971, Presidential Degree 332/1983 and Presidential Degree 3852/2010), the authority to approve a stocking action has passed from the Ministry of Agriculture to the Regional Governor and even to the Mayors. However, any effort towards the protection of the species originates from the implementation of the "The Habitats Directive" 92/43/EEC, through the authority of the Management Body can propose specific periods of fisheries ban and public awareness for the protection of these species.

Author Contributions: Conceptualization, E.K. and A.P.A.; methodology, I.A.G. and A.S.; software, I.A.G.; validation, E.K. and A.S.; formal analysis, I.A.G. and A.S.; investigation, I.A.G., E.K., and A.S.; resources, E.K. and A.P.A.; data curation, A.P.A.; writing—original draft preparation, I.A.G.; writing-review and editing, E.K. and A.P.A.; visualization, A.P.A.; supervision, A.P.A.; project administration, E.K. and A.P.A.; funding acquisition, E.K. All authors have read and agreed to the published version of the manuscript.

Funding: This research received no external funding.

Institutional Review Board Statement: Ethical review and approval were waived for this study since no animal was killed or injured during the methodological procedures. As explained in detail in "2. Materials and Methods" section, all examined trout specimens were collected, provisionally anaesthetised and a small fin tissue piece was obtained, used for DNA extraction. In this manner, the survival of all fishes was secured, and therefore, according to the EU Directive on the protection of animals' usage for scientific purposes (2010/63/EU), no particular permission was needed.

Informed Consent Statement: Not applicable.

Data Availability Statement: Data is contained within the article.

Conflicts of Interest: The authors declare no conflict of interest.

\section{References}

1. Economidis, P.S.; Dimitriou, E.; Pagoni, R.; Michaloudi, E.; Natsis, L. Introduced and tranlocated fish species in the inland waters of Greece. Fisher. Manag. Ecol. 2000, 7, 239-250. [CrossRef]

2. Johnson, B.M.; Arlinghaus, R.; Martinez, P.J. Are We Doing All We Can to Stem the Tide of Illegal Fish Stocking? Fisheries 2009, 34, 389-394. [CrossRef]

3. Apostolidis, A.P.; Stoumboudi, M.Th.; Kalogianni, E.; Cote, G.; Bernatcez, L. Genetic divergence among native trout Salmo trutta populations from southern Balkans based on mitochondrial DNA and microsatellite variation. J. Fish Biol. 2011, 79, 1950-1960. [CrossRef] [PubMed]

4. Apostolidis, A.P.; Madeira, M.-J.; Hansen, M.M.; Machordom, A. Genetic structure and demographic history of brown trout (Salmo trutta) populations from the southern Balkans. Freshwater Biol. 2008, 53, 1555-1566. [CrossRef]

5. Apostolidis, A.P.; Trantaphyllidis, C.; Kouvatsi, A.; Economidis, P.S. Mitochondrial DNA sequence variation and phylogeography among Salmo trutta L. (Greek brown trout) populations. Mol. Ecol. 1997, 6, 531-542. [CrossRef] [PubMed] 
6. Kohout, J.; Šedivá, A.; Apostolou, A.; Stefanov, T.; Marić, S.; Gaffaroglu, M.; Šlechta, V. Genetic diversity and phylogenetic origin of brown trout Salmo trutta populations in eastern Balkans. Biol. Sect. Zool. 2013, 68, 1229-1237. [CrossRef]

7. Koutrakis, E.T.; Sapounidis, A.; Apostolou, A.; Vassilev, M.; Pehlivanov, L.; Leontarakis, P.; Tsekov, A.; Sylaios, G.; Economidis, P.S. An integrated ichthyofaunal survey in a heavily-modified, cross-borded watershed. J. Biol. Res. Thess 2013, 20, 326-338. Available online: http:/ / www.jbr.gr/main/papers20132/16-Koutrakis\%20et\%20al._BIOLOGICAL\%20RESEARCH\%2020.pdf (accessed on 10 June 2021).

8. Economidis, P.S.; Koutrakis, M.; Apostolou, A.; Vassilev, M.; Pehlivanov, L. Atlas of River Nestos Fish Fauna; Prefectural authority of Drama-Kavala-Xanthi, NAGREF-Fisheries Research Institute and Bulgarian Academy of Science: Kavala, Greece, 2009.

9. Kottelat, M.; Freyhof, J. Handbook of European Freshwater Fishes; Publications Kottelat: Cornol, Switzerland, 2007.

10. Simonovic, P.; Maric, S.; Nicolic, V. Trout Salmo spp. complex in Serbia and adjacent regions of the western Balkans: Reconstruction of evolutionary history from external morphology. J. Fish Biol. 2007, 70, 359-380. [CrossRef]

11. Lo Brutto, S.; Hristovski, N.; Arculeo, M. Genetic divergence between morphological forms of brown trout Salmo trutta L. in the Balkan region of Macedonia. J. Fish Biol. 2010, 76, 1220-1227. [CrossRef] [PubMed]

12. Apostolidis, A.P.; Karakousis, Y.; Triantaphyllidis, C. Genetic differentiation and phylogenetic relationships among Greek Salmo trutta L. (brown trout) populations as revealed by RFLP analysis of PCR amplified mitochondrial DNA segments. Heredity 1996, 77, 608-618. [CrossRef] [PubMed]

13. Hillis, D.M.; Moritz, C.; Mable, B.K. Molecular Systematics; Sinauer Associates: Sunderland, MA, USA, 1996 ; Volume 23.

14. Nielsen, E.E.; Hansen, M.M.; Mensberg, K.LD. Improved primer sequences for the mitochondrial ND1, ND3/4 and ND5/6 segments in salmonid fishes: Application to RFLP analysis of Atlantic salmon. J. Fish Biol. 1998, 53, 216-220. [CrossRef]

15. Bernatchez, L. The evolutionary history of brown trout (Salmo trutta L.) inferred from phylogeographic, nested clade, and mismatch analyses of mitochondrial DNA variation. Evolution 2001, 33, 351-379. [CrossRef] [PubMed]

16. Tamura, K.; Peterson, D.; Peterson, N.; Stecher, G.; Nei, M.; Kumar, S. MEGA5: Molecular evolutionary genetics analysis using maximum likelihood, evolutionary distance, and maximum parsimony methods. Mol. Biol. Evol. 2011, 28, 2731-2739. [CrossRef] [PubMed]

17. Cortey, M.; Pla, C.; García-Marín, J.-L. Historical biogeography of Mediterranean trout. Mol. Phylogenet. Evol. 2004, 33, 831-844. [CrossRef]

18. Snoj, A.; Glamuzina, B.; Razpet, A.; Zablocki, J.; Bogut, I.; Lerceteau-Kohler, E.; Pojskic, N.; Susnik, S. Resolving taxonomic uncertainties using molecular systematics: Salmo dentex and the Balkan trout community. Hydrobiologia 2010, 651, 199-212. [CrossRef]

19. Allendorf, F.W.; Luikart, G.; Aitken, S.N. Genetics and the Conservation of Populations, 2nd ed.; Wiley-Blackwell Publishing: Oxford, UK, 2013.

20. Fenichel, E.P.; Tsao, J.I.; Jones, M.; Hickling, G.J. Fish pathogen screening and its influence on the likelihood of accidental pathogen introduction during fish translocations. J. Aquat. Animal Health 2008, 20, 19-28. [CrossRef]

21. Koutsikos, N.; Zogaris, S.; Vardakas, L.; Kalantzi, O.I.; Dimitriou, E.; Economou, A.N. Tracking non-indigenous fishes in lotic ecosystems: Invasive patterns at different spatial scales in Greece. Sci. Total Environ. 2019, 659, 384-400. [CrossRef] [PubMed]

22. Lobón-Cerviá, J.; Sanz, N. (Eds.) Brown Trout: Biology, Ecology and Management; John Wiley \& Sons, Ltd.: Hoboken, NJ, USA, 2018. 